\title{
Para me criar...
}

Jane Tutikian ${ }^{1}$

\begin{abstract}
This essay analyzes the poet Fernando Pessoa, leader of the Movement Orphista, and his contribution to the renewal of the portuguese poetic code. For this, it works with the concepts of fingimento and heteronimia and works with the origin and production of each heteronimo- Alberto Caeiro, Álvaro de Campos and Ricardo Reis - and shows how Fernando is himself the fourth heteronym. The theoretical support for this study is Cleonice Berardinelli, Robert Bréchon, Leyla Perrone-Moisés, José Seabra and others.
\end{abstract}

Keywords: Pretense; Heteronym; Orphismo; Paulismo; Intersectionism; Sensationism.

Resumo: Este ensaio analisa a figura e a contribuição de Fernando Pessoa, líder do Movimento Orphista, para a renovação do código poético português. Para isso, traz os conceitos de fingimento e de heteronimia e trabalha com a origem e a produção de cada um dos heterônimos - Alberto Caeiro, Álvaro de Campos e Ricardo Reis - , e mostra como Fernando Pessoa constitui, ele mesmo, o quarto heteronimo. O suporte teórico foi buscado em Cleonice Berardinelli, Robert Bréchon, Leyla Perrone-Moisés, José Seabra e outros.

Palavras-chave: Fingimento; Heteronimia; Orphismo; Paulismo; Interseccionismo; Sensacionismo.

Introdução

Falar de Fernando Pessoa é sempre um desafio, até porque é falar de vários poetas. E mais ainda, é falar de um poeta que deixou quase 30 mil documentos em uma arca e um curioso envelope que não pode ser aberto. Falar de Fernando Pessoa é falar de um mistificador e de um fingidor. É falar de um menino que passou a infância e o início da adolescência em Durban, na África e teve educação inglesa. É falar, em última análise, como referiu Leyla Perrone-Moisés (1990) de alguém que foi um excesso para Portugal.

É em 1905, aos dezessete anos, que o jovem Pessoa regressa a Lisboa trazendo consigo a mais importante personalidade pré-Caeiro, considerada o embrião do processo heteronímico: Alexander Search.

\section{0 fingimento}

A primeira questão a ser averiguada, quando se começa a pensar em Fernando Pessoa, é o que se entende por lírica moderna. E a lírica moderna é a poesia da dissonância: a poesia do homem fragmentado num mundo fragmentado, do homem em crise num mundo em crise, onde há, portanto, a impossibilidade de unidade e de totalidade. A totalidade é sempre uma falsa totalidade, porque fragmentada e, nessa totalidade fragmentada, há a divisão do sujeito: sujeito lírico e sujeito empírico estão para sempre divididos. Agora, a poesia não mais reproduz o poeta e seu sentimento, mas o sujeito lírico é criado na

1 Escritora e professora titular na Universidade Federal do Rio Grande do Sul 
própria criação do texto. É o momento em que entra em cena o fingidor, como aparece em "Autopsicografia" (s.d. p.223), talvez o poema mais conhecido de Fernando Pessoa:

O poeta é um fingidor.

Finge tão completamente

Que chega a fingir que é dor

A dor que deveras sente.

E os que lêem o que escreve,

$\mathrm{Na}$ dor lida sentem bem,

Não as duas que ele teve,

Mas só a que eles não têm.

E assim nas calhas de roda

Gira, a entreter a razão,

Esse comboio de corda

Que se chama o coração.

Esse poema, paradigmático da teoria assente no princípio do fingimento, traz, em sua primeira estrofe, a reflexão sobre a relação entre o poeta e o fazer poético, na segunda, a relação entre o leitor e o poema, encerrando com uma intensa melancolia por ver a criação poética subjugada ao sentir. É que o sentir de Fernando Pessoa é atravessado pela imaginação/razão. O leitor é que sente com o coração. "Eu simplesmente sinto/ Com a imaginação./ Não uso o coração." "Sentir? Sinta quem lê.“", dirá em «Isto” (Idem. p. 238), uma verdadeira profissão de fé na objetividade da criação poética.

O que Pessoa expressa na "Autopsicografia", e que se completa em "Isto" e em "Guiame a só razão"( Idem. p. 140), é a possibilidade de manifestação textual de uma dor cuja existência é tão somente literária, fingida, não devendo ser confundida com a dor do sujeito empírico. Isso não quer dizer, entretanto, que a dor biográfica, a "que deveras sente", não possa motivar aquela que é literariamente fingida, como acontece em "Autopsicografia", em que as duas são coincidentes. Essa é a teoria pessoana baseada no princípio do fingimento, que não é outra coisa senão uma forma intensa de afirmar a verdade essencial.

Não é demais observar-se que o fingimento pessoano está ancorado na tradição filosófica platônico-aristotélica e na tradição esteticista de Nietzsche.

A mimese platônica diz que a criação é a imitação do nosso entendimento da realidade (a realidade mesma) que por sua vez é imitação da realidade ideal, cabendo à arte um papel inferior de imitação da imitação da imitação.

Assim, o fingimento compactua com a busca da verdade, e esta é a obsessão pessoana que não conhece a realidade - até porque ele é imobilizado por uma espécie de incapacidade de conhecimento da realidade mesma -, ansiando, então, por uma verdade colocada em uma outra realidade, e faz da poesia a expressão deste desespero do não conhecer, mas também única possibilidade de contato com essa realidade outra: "Tudo o que sonho ou passo,/O que me falha ou finda,/ É como que um terraço/ Sobre outra coisa ainda./ Essa coisa é que é linda." ("Isto")

Aristóteles, por sua vez, diz que a arte possibilita o conhecimento da realidade essencial. Deste modo, a mimese aristotélica permite ao poeta fingir a realidade para melhor tocá-la, em outras palavras, sem esse fingimento, a criação estética não é possível, como não o é em Fernando Pessoa ou em Nietzsche, filósofo alemão romântico, precursor do existencialismo, que, em 1884, antecipando a "Autopsicografia" escreveu: "O poeta capaz de mentir/ conscientemente, voluntariamente/ só ele é capaz de dizer a verdade." (Citado por Sena, 1984,p.165)

Em Nietzsche, como repercutirá em Pessoa, a mentira (ou o fingimento) está ligada à expressão do conhecimento da verdade essencial. Fingir (conscientemente, voluntaria- 
mente) é conhecer: "Como o olhar, a razão./ Deus me deu, para ver/ Para além da visão-/ Olhar de conhecer." ("Guia-me a só razão")

Assim, já se pode afirmar, voltando ao conceito inicial de lírica moderna, que a fragmentação em Fernando Pessoa envolve um ato de fingimento que se completa numa linguagem pluridiscursiva, reveladora do sujeito como multiplicidade. Pessoa levou ao extremo a fragmentação, como levou ao extremo o jogo de cena proposto pelo Simbolismo - movimento da virada do século que está na base do primeiro Modernismo português - chegando à despersonalização, criando não um, mas vários sujeitos líricos - entendendo, agora, sujeito lírico como persona, como máscara, como criação - construídos na criação do próprio texto e dele extrapolando.

Deixa-se, então, de falar em subjetividade, a arquitetura poética, antes reprodução, passa a ser reinterpretação, cujo tema central está ligado ao da crise da unidade: o que se tem é uma percepção do real em função do olhar/sensação do sujeito. Em Pessoa, o fingimento, que reformula o conceito de sinceridade, associa-se à atitude de dispersão ou de despersonalização ou como quer Nietzsche, "uma multiplicidade de sujeitos, cuja interação e luta entre si estejam na base do nosso pensamento e, em geral, da nossa consciência" (1974, p. 82) ou, ainda, o novo artista anunciado por Álvaro de Campos, no Ultimatum (1917, p. 34) já que "nenhum artista deverá ter só uma personalidade", o que, levado às últimas conseqüências, gera o fenômeno da heteronímia, os vários sujeitos líricos, portanto, as várias subjetividades.

\section{A heteronímia}

É preciso distinguir heteronímia de pseudonímia.

Na heteronímia, o autor não se esconde sob um nome falso e, muito ao contrário, ele se coloca em posição dialógica com o sujeito lírico que criou , além de assinar a sua própria obra. O autor passa a ser chamado de ortônimo e a sua criação passa a ser chamada de heterônimo, não havendo possibilidade de existência de um sem o outro.

Há, entretanto, condições bem específicas para o surgimento da heteronímia, é preciso que haja a convergência de três fatores: a criação de um nome próprio, a criação de uma biografia própria, e a criação de uma obra marcada por um estilo próprio. Se não houver a conjunção dos três fatores não há heteronímia. Bernardo Soares, por exemplo, autor do Livro do Desassossego, não chega a constituir heterônimo, porque, embora tenha um nome próprio, uma biografia própria, era ajudante de guarda-livros num escritório em Lisboa, e uma obra própria, não tem um estilo próprio. Afirma Fernando Pessoa na famosa carta, de 1935, a Adolfo Casais Monteiro:

(...É um semi-heterónimo porque, não sendo a personalidade a minha, é, não diferente da minha, mas uma simples mutilação dela. Sou eu menos o raciocínio e a afectividade. A prosa, salvo o que o raciocínio dá de ténue à minha, é igual a esta, e o português perfeitamente igual; [...] (s.d. p.205)

Ou, ainda, em Ficções do Interlúdio, onde deixa mais claro:

É que Bernardo Soares, distinguindo-se de mim por suas idéias, seus sentimentos, seus modos de ver e de compreender, não se distingue de mim pelo estilo de expor. $(1996,75)$

Se a origem ou razão da heteronímia é bastante complexa, deve-se considerar, entretanto, que é um fenômeno próprio da passagem do século XIX para o século XX, justamente quando se questiona a unidade e a identidade do sujeito. Jorge de Sena enfatiza que essa tendência na 
viragem do século, se multiplica nas literaturas ocidentais que se dirigem ao esteticismo de vanguarda, -Eliot, Gide...- recorrem a este tipo diverso do personagem que não são pseudônimos. Nenhum criou uma independência completa. Com vidas, estilos e pensamentos próprios e em fazê-las viver a seu lado não só no espaço literário como no tempo de vida. Os outros partem, Fernando Pessoa fica. (1984, p.165)

Para Carlos Reis (1995, p.66) o fenômeno não é exclusivo de Pessoa "que lhe deu, no entanto, reconhecidamente, uma dimensão e uma profundidade únicas" e os limites dessa relação ortônimo-heterônimo nem sempre são claros, como são em Fernando Pessoa, citando algumas tentativas, ou aproximações como: Eça de Queirós-Fradique Mendes, no teatro e na novelística de Pirandello, na poesia de Ezra Pound, etc.

Ainda que se possa afirmar que a base do fenômeno heteronímico está na dispersão e que a dispersão é fenômeno geracional (Florbela Espanca e Mário de Sá Carneiro são exemplos), a explicação de sua origem compete ao próprio Pessoa.

Diz ele na carta a Casais Monteiro:

[...] a origem mental dos meus heterônimos está na minha tendência orgânica e constante para a simulação. [...] Desde criança tive a tendência para criar em meu torno um mundo fictício, de me cercar de amigos e conhecidos que nunca existiram. [...] Lembro, assim, o que me parece ter sido o meu primeiro heterónimo, ou, antes, o meu primeiro conhecido inexistente - um certo Chevalier de Pas dos meus seis anos, por quem escrevia cartas dele a mim mesmo, e cuja figura, não inteiramente vaga, ainda conquista aquela parte da minha afeição que confina com a saudade. [...] foi em 8 de Março de 1914 - acerquei-me de uma cómoda alta, e, tomando um papel, comecei a escrever, de pé, como escrevo sempre que posso. E escrevi trinta e tantos poemas a fio, numa espécie de êxtase cuja natureza não conseguirei definir. Foi o dia triunfal da minha vida, e nunca poderei ter outro assim. Abri com um título, O Guardador de Rebanhos. E o que se seguiu foi o aparecimento de alguém em mim, a quem dei desde logo o nome de Alberto Caeiro. Desculpe-me o absurdo da frase: aparecera em mim o meu mestre. Foi essa a sensação imediata que tive. E tanto assim que, escritos que foram esses trinta e tantos poemas, imediatamente peguei noutro papel e escrevi, a fio, também, os seis poemas que constituem a Chuva Oblíqua, de Fernando Pessoa. Imediatamente e totalmente... Foi o regresso de Fernando Pessoa-Alberto Caeiro a Fernando Pessoa ele só. Ou, melhor, foi a reacção de Fernando Pessoa contra a sua inexistência como Alberto Caeiro. Aparecido Alberto Caeiro, tratei logo de lhe descobrir - instintiva e subconscientemente - uns discípulos. (s.d. p. 205)

Mas, do ponto de vista teórico, explica Pessoa em Páginas Íntimas e de Auto-Interpretação:

Dividiu Aristóteles a poesia em lírica, elegíaca, épica e dramática. Como todas as classificações bem pensadas, é esta útil e clara; como todas as classificações, é falsa. Os géneros não se separam com tanta facilidade íntima, e, se analisarmos bem aquilo de que se compõem, verificaremos que da poesia lírica à dramática há uma gradação contínua. [...] Dê-se o passo final, e teremos um poeta que sela vários poetas, um poeta dramático escrevendo em poesia lírica. Cada grupo de estados de alma mais aproximados insensivelmente se tornará uma personagem, com estilo próprio, com sentimentos porventura diferentes, até opostos, aos típicos do poeta na sua pessoa viva. E assim se terá levado a poesia lírica - ou qualquer forma literária análoga em sita substância à poesia lírica - até à poesia dramática, se todavia se lhe dar a forma de drama, nem explícita nem implicitamente. [...]

Por qualquer motivo temperamental que me não proponho analisar, nem importa que analise, construí dentro de mim várias personagens distintas entre si e de mim, personagens essas a que atribuí poemas vários que não são como eu, nos meus sentimentos e ideias, os escreveria.

Assim têm estes poemas de Caeiro, os de Ricardo Reis e os de Álvaro de Campos que ser considerados. Não há que buscar em quaisquer deles ideias ou sentimentos meus, pois muitos deles exprimem ideias que não aceito, sentimentos que nunca tive. Há simplesmente que os ler como estão, que é aliás como se deve ler.(1966, p.106) 
É dentro desse raciocínio de uma espécie de gradação de afastamento do sentimento próprio do sujeito empírico, até chegar à mais completa despersonalização, que Fernando Pessoa, que se diz acima de tudo um poeta dramático, traz a melhor definição para seus heterônimos: "personagens fictícias sem drama" (Idem. p. 109) ou, se se quiser, personagens dramáticas descontextualizadas.

Fazem parte da "galáxia pessoana", três heterônimos: Alberto Caeiro, Ricardo Reis e Álvaro de Campos, um semi-heterônimo: Bernardo Soares, e, nas últimas décadas foram encontradas mais de 100 personalidades literárias (pequenos heterônimos).

\section{Alberto Caeiro, o mestre}

O "dia triunfal" - 8 de Março de 1914 - marca o aparecimento do mestre de Pessoa e dos demais heterônimos, marca o aparecimento de Alberto Caeiro com os poemas que compõem $O$ Guardador de Rebanhos, escritos de um só fôlego. Quem é Alberto Caeiro? Fernando Pessoa responde como o "vê". Tomemos alguns fragmentos da carta, já referida, a Adolfo Casais Monteiro, de 1935:

Alberto Caeiro nasceu em 1889 e morreu em 1915; nasceu em Lisboa, mas viveu quase toda a sua vida no campo. Não teve profissão nem educação quase alguma.

Caeiro era de estatura média, e, embora realmente frágil (morreu tuberculoso), não parecia tão frágil como era.

Cara rapada todos - o Caeiro louro sem cor, olhos azuis; [...]

Caeiro, como disse, não teve mais educação que quase nenhuma - só instrução primária; morreram-lhe cedo o pai e a mãe, e deixou-se ficar em casa, vivendo de uns pequenos rendimentos. Vivia com uma tia velha, tia-avó.

Como escrevo em nome desses três?... Caeiro, por pura e inesperada inspiração, sem saber ou sequer calcular o que iria escrever $[\ldots]$

Caeiro escrevia mal o português, $[\ldots]$

É, ainda, na carta, que Pessoa afirma ter posto em Alberto Caeiro todo o seu "poder de despersonalização dramática". De fato, seu mestre é, também, seu mais diferente heterônimo. Se em Fernando Pessoa, "O que em mim sente 'stá pensando"(s.d.p.111), em Caeiro, tudo acontece ao contrário: "Procuro dizer o que sinto/ Sem pensar em que o que sinto.’(s.d., Poema XXXIV. p. 57

O heterônimo surge como um revide irônico ao Saudosismo de Teixeira de Pascoaes, movimento místico-panteísta. Assim, se o fazer poético surge da tensão entre o real e o pensamento, Alberto Caeiro elimina o pensamento e esta é a sua grande marca: o fim do pensar e da metafísica: "tudo é como é e assim é que é." Vejamos um fragmento do poema $\mathbf{V}$ de $O$ Guardador de Rebanhos (Idem.p.26):

Há metafísica bastante em não pensar em nada.

O que penso eu do mundo?

Sei lá o que penso do mundo!

Se eu adoecesse pensaria nisso.

Que idéia tenho eu das cousas?

Que opinião tenho sobre as causas e os efeitos?

Que tenho eu meditado sobre Deus e a alma

E sobre a criação do Mundo? 
$[\ldots]$

O mistério das cousas? Sei lá o que é mistério!

$\mathrm{O}$ único mistério é haver quem pense no mistério.

[...]

"Constituição íntima das cousas"...

"Sentido íntimo do Universo"...

Tudo isto é falso, tudo isto não quer dizer nada.

[...]

O único sentido íntimo das cousas

É elas não terem sentido íntimo nenhum.

O primeiro verso desta ode V é, já, o verso inaugural do projeto de Alberto Caeiro, a celebração da realidade mesma, visível, percebida pelos sentidos, em oposição ao ideal concebido pelo espírito, encontrado na pura transcendência. "Há metafísica bastante em não pensar em nada", propõe o poeta.

Irônico, ele relaciona o pensar à doença. Fora dela, não há razão para pensar e, porque não há razão para pensar, desfaz das relações filosóficas de causa e efeito, das entidades teológicas Deus e alma e da explicação da criação do mundo. Ataca os filósofos e os poetas - "O único mistério é haver quem pense nos mistérios" - incapazes que são de perceber a luz do sol - aqui representando a Natureza - que vale mais do que os seus pensamentos. A Natureza, o "ser imanente que suporta e anima tudo o mais.", a "qualidade de tudo o que pertence ao mundo sensível, visível, infra-humano", conforme Bréchon (1998, p. 210) é, por isso mesmo perfeita, "não sabe o que faz", não pensa "E por isso não erra e é comum e boa".

À metafísica, à realidade transcendente ao mundo dos fenômenos físicos, o poeta propõe outra: "Há metafísica bastante em não pensar em nada", ou seja, a metafísica da não-metafísica: " Mas que melhor metafísica que a delas" (as árvores/ a Natureza) "Que é a de não saber para que vivem/ Nem saber que o não sabem?” Diante desta metafísica da não-metafísica da Natureza toda a transcendência é inútil "como levar um copo à água das fontes.", até porque "O único sentido íntimo das coisas / É elas não terem sentido íntimo nenhum."

É como Caeiro nega o mistério do mundo e, nisso, ele é diferente de todos os outros, os seus discípulos, não quer perceber demais, não quer elaborações mentais, não quer interferência no seu contato com a Natureza, procurando com ela uma relação através da sensação pura, sem a intervenção da memória, sem o pensamento, o que constitui uma traição à própria Natureza. Nesse sentido, a compreensão é mais uma realização dos sentidos do que da inteligência, reduz o ser ao parecer e opõe-se à significação oculta.

Deus não é uma questão prioritária em Alberto Caeiro, ele recusa a cultura judaicocristã, fundada na crença do pecado original, e cria neopaganismo, movimento filosófico, político e estético, que terá Ricardo Reis como seguidor, buscando nos clássicos gregos e romanos a objetividade pura que o Cristianismo arruinou. Resta, portanto, a Natureza enquanto perfeição e é, aí, que pensa em Deus, pensa sem pensar, pensa "vendo e ouvindo". Quer dizer: não nega a sua dimensão divina - como não nega a dimensão do mundo, a do homem, a da vida - mas transforma-o em presença, na Natureza, e amando-o sem pensar nele, anda "com ele a toda a hora".

Na verdade, o que Caeiro busca é a inocência primitiva, onde a consciência das coisas não é, necessariamente, a consciência de si mesmo, nem está em Deus: “(Que mais sei eu de Deus que Deus de si próprio?)“. É o retorno da consciência pré-reflexiva do homem mítico, ligado a si e ao mundo sem experimentar as diferenças, sem querer superar a fragmentação, ela não existe, pois não existe a interioridade, sem querer buscar a totalidade. 
A consciência reflexiva, a que esconde as emoções verdadeiras, porque é "a tinta com que me pintaram os sentidos", ela é que é a infelicidade.

Esse sentimento volta-se para o ato da escrita e para a imagem que o poeta tem de si próprio:

\section{$[\ldots]$}

Procuro dizer o que sinto

Sem pensar em que o sinto.

$[\ldots]$

Nem sempre consigo sentir o que sei que devo sentir.

$\mathrm{O}$ meu pensamento só muito devagar atravessa o rio a nado

Porque lhe pesa o fato que os homens o fizeram usar.

Procuro despir-me do que aprendi,

Procuro esquecer-me do modo de lembrar que me ensinaram,

E raspar a tinta com que me pintaram os sentidos,

Desencaixotar as minhas emoções verdadeiras,

Desembrulhar-me e ser eu, não Alberto Caeiro,

Mas um animal humano que a Natureza produziu.

$[\ldots]$

Ainda assim, sou alguém.

Sou o Descobridor da Natureza.

Sou o Argonauta das sensações verdadeiras.

Trago ao Universo um novo Universo

Porque trago ao Universo ele-próprio. (s.d. p.66)

$[\ldots]$

Caeiro é um solitário que não estabelece relações com os outros. Vive para a simplicidade da Natureza e volta para a Natureza pela morte. É o que Nietzsche (1974) define como o ingênuo, este abandono completo à beleza da aparência. Essa concepção ingênua e objetiva das coisas, a despeito de tudo o que pensa do não pensar, produz uma poesia pensada.

Curioso que, dessa forma, sendo contra a metafísica, o mestre questiona a filosofia, a teologia e termina criando um verdadeiro projeto antipoético. Ele recusa as características convencionais da poesia nas suas odes modernas, seja do ponto de vista formal, seja do ponto de vista temático, seja pela intenção de abolir a linguagem figurada, até porque "... as estrelas não são senão estrelas/ Nem as flores senão flores,/ Senão por isso que lhes chamamos estrelas e flores."(s.d. Poema XXIV. p.48), roubando-lhe a pluralidade de significados que coexistem em um só significante, como refere Umberto Eco, na sua Obra Aberta (2013), seja por roubar à poesia as suas qualidades metafísicas, pois "O único sentido íntimo das coisas/ É elas não terem sentido íntimo nenhum”.

Este é Alberto Caeiro, o poeta de $O$ guardador de rebanhos, Poemas inconjuntos e Pastor amoroso, simples e complexo na sua simplicidade de "animal humano", este "Descobridor da Natureza", este "Argonauta das sensações verdadeiras", segundo Álvaro de Campos, em "Notas para a Recordação do meu Mestre": não um outro homem, mas "um outro universo", "a voz da terra que é tudo e ninguém.»

\section{Ricardo Reis, o clássico}

A idéia de criação de um poeta clássico antecede o dia triunfal. Foi por volta de 1912 , diz Pessoa na carta a Adolfo Casais Monteiro, que teve a idéia de escrever alguns poemas de índole pagã, mas terminou abandonando. "Esboçara-se-me, contudo, numa penumbra mal urdida, um vago retrato da pessoa que estava a fazer aquilo. (Tinha nascido, sem que eu soubesse, o Ricardo Reis.)" 
Este é o Ricardo Reis visto por Fernando Pessoa:

Ricardo Reis nasceu em 1887 (não me lembro do dia e mês, mas tenho-os algures) no Porto, é médico e está presentemente no Brasil.

Ricardo Reis é um pouco, mas muito pouco, mais baixo, mais forte, mas seco. (Do que Caeiro, que era de estatura média)

Cara rapada todos - [...] Reis de um vago moreno mate; [...]

Ricardo Reis, educado num colégio de jesuítas, é, como disse, médico; vive no Brasil desde 1919, pois se expatriou espontaneamente por ser monárquico. É um latinista por educação alheia, e um semi-helenista por educação própria.

Como escrevo em nome desses três? [...] Ricardo Reis, depois de uma deliberação abstrata, que subitamente se caracteriza numa ode.

Reis escreve melhor do que eu, mas com um purismo que considero exagerado. O difícil para mim é escrever a prosa de Reis -ainda inédita - [...] (s.d. p.193)

Em certo momento dessa carta, afirma Pessoa: "Pus no Ricardo Reis toda a minha disciplina mental, vestida da música que lhe é própria.” Essa colocação e, sobretudo, a palavra disciplina nos fornecem elementos importantes para o conhecimento de Ricardo Reis. É a disciplina que o faz mascarar a tensão entre o real e o pensamento, criando um falso equilíbrio, através da contemplação e, diferentemente de Caeiro, disciplina o pensamento que, por sua vez, disciplina a sensação. Reis é o oposto total de Fernando Pessoa, ele representa uma grande conciliação, o que o ortônimo jamais alcançou, mas uma conciliação enganosa, melancólica, forjada pela disciplina. Estamos, portanto, diante do heterônimo clássico de Fernando Pessoa, o heterônimo que se expressa através de poemas neoclássicos, de odes conexionadas a Horácio.

Quando se afirma a conexão de Ricardo Reis a Horácio, se afirma formalmente (as odes clássicas, ricas em inversões vocabulares), mas também relacionada a uma cosmovisão que alia duas tradições o estoicismo (com seu alto poder de aceitação e de resignação) e o epicurismo (o supremo bem está no prazer).

Ricardo Reis é o culto do instante, o carpe diem, é o epicurismo a se revelar pelo prazer equilibrado, puro, duradouro. É o "prazer, mas devagar.” (Ode XIX. p. 93). Mas é, também, a consciência da transitoriedade, da presença constante da morte:

Tão cedo passa tudo quanto passa!

Morre tão jovem ante os deuses quanto

Morre! Tudo é tão pouco!

Nada se sabe, tudo se imagina.

Circunda-te de rosas, ama, bebe

E cala. O mais é nada.(Idem.p.92)

Essa é a ode paradigmática da percepção de mundo de Ricardo Reis. Ele sofre diante dos mistérios da vida e da morte, mas, diferentemente de Pessoa, tenta escapar do sofrimento pelo prazer equilibrado e tranqüilo.

Como pólo masculino da família heteronímica pessoana, o poeta traz figuras femininas, mas a relação que procura com elas é sempre uma relação inconsistente, porque quer uma relação que não lhe deixe recordações tristes ou nenhuma espécie de desassossego:

Vem sentar-te comigo Lídia, à beira do rio.

Sossegadamente fitemos o seu curso e aprendamos 
Que a vida passa, e não estamos de mãos enlaçadas.

(Enlacemos as mãos.)

$[\ldots]$

Desenlacemos as mãos, porque não vale a pena cansarmo-nos.

Quer gozemos, quer não gozemos, passamos como o rio.

Mais vale saber passar silenciosamente

E sem desassossegos grandes.

Sem amores, nem ódios, nem paixões que levantam a voz,

Nem invejas que dão movimento demais aos olhos,

Nem cuidados, porque se os tivesse o rio sempre correria,

E sempre iria ter ao mar.

[...]

Pagãos inocentes da decadência.

É em nome do não sofrimento que Ricardo Reis opta pela inocência de "crianças adultas", abdica dos grandes sentimentos porque o fim é sempre o mesmo: a morte.

A morte é uma das grandes preocupações de Reis, com a mesma visão mitológica de Horácio e alguma influência de Homero, porque ela é presença e desconhecimento. "Nada se sabe, tudo se imagina." Sua chegada é simbolizada pelas figuras de Atropos e das outras Parcas, as deusas que dobram e cortam a vida, e é o mar assustador onde desemboca o rio da vida, ou é o rio negro, ou a oculta margem, ou é o abismo oposto ao mundo, mas pode ser, também, um grande sono de que se possa acordar algum dia.

Há um destino que dirige os homens (e os deuses) segundo uma lei indiscutível e irreversível. Estamos, portanto, como na tragédia grega, diante do fado. É a "lei inimplorável". Agora, ao epicurismo e ao estoicismo, associa-se uma filosofia niilista - diferenciada da de Álvaro de Campos - marcada não pela irreverência, mas pela aceitação.

Para Bréchon (Op.cit. p. 224), a filosofia de Reis é de um niilismo total, para Leyla Perrone-Moisés (1990,p.56), é esse niilismo que revela a miserabilidade da condição humana, o que, em Bréchon se transforma no aspecto mais clássico e talvez mais banal de Reis.

Se em Campos a vida é um jogo de apostas, em Reis, é um jogo que não se pode ganhar, é quando ele assume a ataraxia grega (um eixo imóvel em torno do qual gira o tempo) e a contemplação. É quando adota a ética da aceitação total ou a ética da abdicação: não quer nada e não espera nada, sem grandes desassossegos, sem amores nem ódios,: “ Se não amo, nem bebo,/Nem sem querer não penso, [...]", como uma tentativa de manter, ainda, sua liberdade, de possuir a si próprio.

\section{$[\ldots]$}

Colhe as flores mas larga-as,

Das mãos mal as olhaste.

Senta-te ao sol. Abdica

E sê rei de ti próprio. (s.d. p.30)

Mas se „Não há tristezas/ Nem alegrias/ Na nossa vida./ Assim saibamos,/ Sábios incautos,/ Não a viver"( Idem. p. 13) e, se tudo passa, os versos restam. Pois são os versos - que fixam os reflexos do mundo, que não se submetem ao esquecimento, que terminam por revelar o falso "Leve descanso / De estar vivendo" ou a falsa tranqüilidade da morte "tendo/ Nem o remorso/ De ter vivido. "(Idem. p. 13)- os portadores do que Fernando Pessoa assim define: "A obra de Ricardo Reis, profundamente triste, é um esforço lúcido e disciplinado para obter uma calma qualquer."(1996,p.386) Não mais do que um esforço. 


\section{5 Álvaro de Campos, a modernidade}

Se, em Caeiro, Fernando Pessoa colocou todo o seu poder de despersonalização e se, em Reis, colocou toda a sua disciplina mental, em Álvaro de Campos, colocou a emoção: " pus em Álvaro de Campos toda a emoção que não dou nem a mim nem à vida." (1996,p.386)

[...]Álvaro de Campos (o mais histericamente histérico de mim) [...]

Álvaro de Campos nasceu em Tavira, no dia 15 de Outubro de 1890 (às 1,30 da tarde, diz-me o Ferreira Gomes; e é verdade, pois, feito o horóscopo para essa hora, está certo). Este, como sabe, é engenheiro naval (por Glasgow), mas agora está aqui em Lisboa em inactividade.

Álvaro de Campos é alto (1,75 in de altura, mais $2 \mathrm{~cm}$ do que eu), magro e um pouco tendente a curvar-se. Cara rapada todos - [...] Campos entre branco e moreno, tipo vagamente de judeu português, cabelo, porém, liso e normalmente apartado ao lado, monóculo.

Álvaro de Campos teve uma educação vulgar de liceu; depois foi mandado para a Escócia estudar engenharia, primeiro mecânica e depois naval. Numas férias fez a viagem ao Oriente de onde resultou o Opiário. Ensinou-lhe latim um tio beirão que era padre. Como escrevo em nome desses três?[...] Campos, quando sinto um súbito impulso para escrever e não sei o quê.

Pode-se falar em três momentos distintos na poesia de Álvaro de Campos: um de uma poesia fortemente influenciada pelo Simbolismo-Decadentismo, da virada do século, de que "Opiário", ainda metrificando e rimando, é o grande paradigma, revelando um Campos "em botão", pré-Caeiro; o segundo, o da euforia da modernidade, futurista, o de "Ode Moderna" ; o terceiro, o da melancolia da modernidade, marcado por poemas como "Tabacaria" ou Tabacaria.

Álvaro de Campos é o heterônimo mais próximo de Fernando Pessoa. Pessoa. Bréchon afirma, com propriedade, que é o seu "duplo extrovertido". (Op. cit. p.235) Ele é emoção pura, é o poeta da sensação. Entre o pensamento e a ação quer os dois: quer "sentir tudo de todas as maneiras", "quer ser toda a gente e toda a parte."

Pós-Caeiro, inaugura-se como um poeta whitminiano (V. Ode a Walt Whitman), com métrica livre e linguagem cotidiana, com suas odes cheias de contraste e de euforia, com um ritmo febril, com seu culto à velocidade, à máquina, à modernidade. Como Whitman, ele é a liberdade, a irreverência e a prosificação da poesia:

$[\ldots]$

Ah, e a gente ordinária e suja, que parece sempre a mesma,

Que emprega palavrões como palavras usuais,

Cujos filhos roubam às portas das mercearias

E cujas filhas aos oito anos - e eu acho isto belo e amo-o!

A gentalha que anda pelos andaimes e que vai para casa

Por vielas quase irreais de estreiteza e podridão.

Maravilhosa gente humana que vive como os cães,

Que está abaixo de todos os sistemas morais,

Para quem nenhuma religião foi feita,

Nenhuma arte criada,

Nenhuma política destinada para eles!

Como eu vos amo a todos, porque sois assim,

Nem imorais de tão baixos que sois, nem bons nem maus,

Inatingíveis por todos os progressos, 
Fauna maravilhosa do fundo do mar da vida!

$[\ldots]$

Engenhos, brocas, máquinas rotativas!

Eia! eia! eia!

Eia eletricidade, nervos doentes da Matéria!

Eia telegrafia-sem-fios, simpatia metálica do Inconsciente!

Eia túneis, eia canais, Panamá, Kiel, Suez!

Eia todo o passado dentro do presente!

Eia todo o futuro já dentro de nós! eia!

Eia! eia! eia!

Frutos de ferro e útil da árvore-fábrica cosmopolita!

Eia! eia! eia, eia-hô-ô-ô!

Nem sei que existo para dentro. Giro, rodeia, engenho-me.

Engatam-me em todos os comboios.

Içam-me em todos os cais.

Giro dentro das hélices de todos os navios.

Eia! eia-hô eia!

Eia! sou o calor mecânico e a eletricidade!

Eia! e os rails e as casas de máquinas e a Europa!

Eia e hurrah por mim-tudo e tudo, máquinas e trabalhar, eia!

Galgar com tudo por cima de tudo! Hup-lá!

Hup-lá, hup-lá, hup-lá-hô, hup-lá!

Hé-lá! He-hô Ho-o-o-o-o!

Z-z-z-z-z-z-z-z-z-z-z-z!

Ah não ser eu toda a gente e toda a parte!(s.d. 144)

„Ode Triunfal“ não é, senão, a euforia crescente, uma espécie de surto da modernidade, e a modernidade é tudo, é o presente que engole o passado e o futuro, é a civilização cotidiana, com seus seres malditos, a sua gente ordinária, é a beleza da máquina com o seu momento ruidoso e mecânico. Tudo cantado de forma excitada e excessiva, num poema repleto de onomatopéias e de pontos de exclamação, apesar da estrutura relativamente simples. O único momento em que o poeta se permite um lirismo maior é aquele em que lembra da infância. Então, numa estrofe de dez versos, colocada entre parênteses, quebra o tom geral do poema- esses, aliás, são recursos e temas recorrentes em Campos- para retomá-lo adiante, e fundir-se com a máquina, num ritmo desenfreado, e lamentar-se não ser "toda a gente e toda a parte".

Tudo se dá em nome de um "querer viver aos extremos". E, de fato, Campos vive aos extremos: depois da euforia vem a disforia, depois da exaltação vem a depressão, e a modernidade ganha outra face, ao ritmo desenfreado de "Ode Triunfal" segue-se o tédio da inutilidade e dos sonhos não realizados, e mediando esse processo, a impossibilidade de unidade do sujeito.

Impressiona, em Álvaro de Campos, o processo de narrativização da poesia, seja pelo poder de descrição, seja pelas pessoas que participam da arquitetura do poema, seja pela imposição do espaço.

É o que, em meu entender, sucede nos poemas de Campos. São um extravasar de emoção. $[\ldots]$

O que verdadeiramente Campos faz, quando escreve em verso, é escrever prosa ritmada com pausas maiores marcadas em certos pontos, para fins rítmicos, e esses pontos de pausa maior, determina-os ele pelos fins dos versos. Campos é um grande prosador, um prosador com uma grande ciência do ritmo; mas o ritmo de que tem ciência, é o ritmo da prosa[...],

afirma Ricardo Reis em sua "Nota Preliminar".

Num ritmo de prosa e de extravasar de emoção, "Poema em linha reta", poema da fase madura de Álvaro de Campos, é a própria trajetória da dissolução do sujeito, que olha 
para si e se vê apenas como um estranho na vida. Em "Tabacaria“", por exemplo, encontrase como o que falhou em tudo, na nostalgia de ter perdido a inocência e na náusea, antecipando Sartre. Mesmo as pessoas que vê da janela - a gente uma igual à outra - provocam nele a angústia da banalidade. Ele é um solitário imobilizado pelo excesso de uma lucidez destruidora de si - "[...] invoco/A mim mesmo e não encontro nada" - e do mundo em que é apenas um estrangeiro, e a voz de Deus vem de um "poço tapado".

É que, diante da janela e da rua, diante da Tabacaria que vê da janela, Álvaro de Campos enfrenta o nada que é. E o que é, é uma espécie de epopéia de um fracasso absoluto, onde "todos os sonhos do mundo", a parte não ser nada, se decompõem e o universo se reconstrói "sem ideal nem esperança", e o dono da Tabacaria sorri.

Leyla Perrone-Moisés (Op.cit. p. 141) diz que Campos é a ficção mais rica de Fernando Pessoa, porque é a "contradição em processo", e de fato é, é a criação que melhor ilustra o fragmento, o enigma e o pavoroso acaso nietzschianos. Para a velha crítica, representada por João Gaspar Simões, Campos é o heterônimo mais falso ( em oposição a Caeiro - marcado pela sinceridade e mestre), para a nova crítica, se a falsificação relaciona-se a fingimento e se o fingimento relaciona-se, em Pessoa, à verdade, então, Campos é o mais verdadeiro, nele, "a ficção se afirma como forma de conhecimento." ( Idem. p. 141)

Campos é tão verdadeiro, que é a criatura a sobreviver, de fato, ao criador. Já se disse que Campos é guiado pela emoção, Fernando Pessoa, pela razão, mas, no ano da sua morte (1935), a razão não dá conta do viver. Todos os poemas escritos nos últimos meses não são assinados por ele, são assinados por Álvaro de Campos. Como poeta, Fernando Pessoa morrei antes de Campos, a critura que queria ser toda a gente em toda a parte.

\section{0 criador dos "ismos lusos"}

Pessoa foi um grande teórico. Em 1912, liga-se a Teixeira de Pascoais e passa a colaborar na Revista A Águia como ensaísta e teórico do Saudosismo (Movimento estéticodoutrinário místico-panteísta, liderado por Teixeira de Pascoais, que busca recuperar a glória portuguesa, revisando as mais autênticas tradições da pátria através da saudade.) que, três anos mais tarde, abandona para liderar o grupo Orpheu, introdutor do Modernismo em Portugal.

A Revista Orpheu tem vida curta ( não mais do que três números: dois em 1915, financiados pelo pai de Mário de Sá-Carneiro) e um terceiro que só veio a ser publicado em 1983), entretanto, tempo suficiente para renovar o código poético português.

Na verdade, é o momento de mudanças em todos os campos: desaparecem as relações estáveis, são rompidos os conceitos vinculados à tradição, o sagrado se profaniza, instaurase a atomização do real e a dialética entre a interioridade e a exterioridade, a racionalidade se fragiliza na sustentação das ideologias não esclarecidas, o ceticismo e a iconoclastia se alojam destruindo mitos, dessacralizando espaços e idéias e incorporando os diferentes ideários e expressões dos "ismos" europeus - sobretudo o Futurismo - e dos "ismos" lusos: Paulismo, Sensacionismo, Interseccionismo, criados pelo líder do Orphismo.

Vale, aqui, a conceituação dos "ismos" lusos. Segundo Antônio Sérgio, Fernando Pessoa inaugura, em 1914, na revista A Águia, uma pratica poética correspondente às suas considerações como crítico, com o poema "Impressões do Crepúsculo". Quer dizer: realiza no poema aquilo que propõe em quanto crítico. O Paulismo torna-se o primeiro degrau e a primeira linha de força do que vai ser definido como Sensacionismo, que é a grande contribuição estética de Orpheu, não só por singularizar o Modernismo Português, mas por estabelecer uma de suas linhas de força que foi o seu traço de extensão com o Simbolismo.

Ele funde a concepção dadaísta - segundo Benjamin, a "experiência de Choque" - que é retomada com o marco do Futurismo - à herança do Simbolismo - com a desconstrução 
de termas e de tratamentos de linguagem poética.

Do ponto de vista da linguagem, o Paulismo se caracteriza pela liberação do sentido da imagem, fazendo com que o significado desta seja subordinado ao seu correspondente significante. No Paulismo e no Sensacionismo, que daí se desdobra, o sentido presente não remete a um encadeamento lógico e racional e, conseqüentemente, a uma decodificação no nível da comunicação automatizada. Ora, o significante repousa no primado da imagem e a liberação aludida - e referente ao âmbito do sentido, do significado - dá-se em relação ao significante, o que vai significar, literalmente, o sentido conforme a fonológica tradição simbolista que ai é simplesmente mantida. O Simbolismo apostara no verso branco, na aliteração, na sinestesia, dependia do jogo fonético dos significantes e não do que estava automatizado e condenado a estabelecer uma necessária relação de conteúdo. Portanto, tratava-se de uma libertação imagética. Esta libertação imagética permitiu a violação da sintaxe gramatical, ou seja, daquilo que foi inaugurado como contribuição da autonomia do significante no âmbito do Simbolismo: verso branco; uso significativo do branco da pagina; ênfase de sentido na rima interna através dos recursos da aliteração e da sinestesia. No Paulismo, esta violação se dirige ao âmbito da interpenetração das características morfológicas - violação da sintaxe gramatical, uso de frase nominal, retomada de grafema simbolista.

Assim, a relação do Orphismo com o Simbolismo é fruto de uma relação direta com o Paulismo, existente na citada incorporação e modificação de todos aqueles procedimentos que vêm da tradição simbolista e se radicalizam no Paulismo.

Para Almada Negreiros, o termo Paulismo remete a "Paludes", de André Gide, o que ampliaria a sua relação de fonte e dependência com o tipo de Simbolismo que remete à matriz de Camilo Pessanha. O Simbolismo incorporado por Montalvor, Guisado, Côrtes-Rodrigues, Álvaro de Campos e basicamente pela prosa de Sá-Carneiro não é o Mallarmaico (como em Eduardo Guimarães), mas o de Baudelaire e Rimbaud.

Por outro lado, o efeito estético desta importação tradutora do Futurismo vai dialogar com a retomada da tradição simbolista, que tinha sido inoculada no moderno pelo poema "Paúis", Isto é, pelo pós-Simbolismo paúlico, também conhecido como Paulismo. Devese sempre falar em Orpheu na alternância Simbolismo-Paulismo ou gerando a relação Futurismo - Sensacionismo.

O Interseccionismo, por sua vez, é o Paulismo Radicalizado, o Paulismo é o Sensacionismo contido, portanto torna-se passagem obrigatória entre o Simbolismo e a posteridade sensacionista.

O primeiro procedimento significa tomar a palavra, despida de uma expectativa lógicoconceitual, de significação, que remete ao panteísmo, ao transcedentalismo. A 1 dimensão $^{\text {a dima }}$ equivale à constituição fonológica da imagem para provocar sensações senestésicas. (Impressão do Crepúsculo -Fernando Pessoa): Na segunda, trata-se de, através da palavra, assim constituída, representar referencialmente um objeto sólido. A palavra é constituída no nível do significante para que se preste a representar sensações e provocá-las. (Chuva Obliqua - F.P.) Na terceira a própria palavra se confunde, com o ícone, com o objeto sólido que representava. A palavra é ela própria um objeto sólido. (Ode triunfal -

Álvaro de Campos.

Para o Interseccionismo, as palavras são objetos verbais. Sensação é igual a imagem. Assim, ele é a interseção entre palavras e imagens.

O Sensacionismo é dar à palavra a objetividade máxima, é transformar a palavra em objeto sólido. 
O Orphismo é a síntese de todos os “ismos” que estão em sua base - Simbolismo Decadentismo, Construtivismo Cubista, nacionalista - todas estas construções convergem para o "ïsmo" singular do Orphismo, que é sensacionista.

Se o Sensacionismo é a própria síntese do projeto estético da revista Orpheu, não vai ser apenas a sua contribuição estética, é uma apreensão da existência, uma vez que coloca-se acima do real. Não existe o real, tudo o que existe é a sensação, são as sensações.

Assim, vem do grupo do Orpheu, o máximo da contribuição estética do Modernismo português como obra de vanguarda, até porque, por não considerar o Orphismo um movimento, no sentido tradicional, ele não era excludente dos "ïsmos"que sintetizara para origina-se, ele era o incorporador dos mesmos, era o Sensacionismo.

\section{Conclusões finais: Um quarto heterônimo: o líder Orphista}

Jorge de Sena escreveu a respeito de Pessoa um texto a que chamou "O homem que nunca existiu"(1977), Michel Schneider escreveu "Personne" (ninguém) (1984) e Leyla Perrone-Moisés, "Pessoa ninguém?"(1990)

Jorge de Sena fala de um heterônimo especial: Fernando Antonio Nogueira Pessoa. Não um eu, mas um anti-eu. E reafirma: Lado a lado com os heterônimos, Fernando Pessoa não é menos heterônimo do que os outros. O poeta que na vida civil se chamou Fernando Nogueira Pessoa não é o mesmo Fernando Pessoa. O ortônimo é marcado pelo desespero existencial. Fernando Pessoa escolheu "não ser". O não ser está vinculado à incapacidade de vida real. (1984, p.179)

Michel Schneider escreve:

Tudo foi tão confuso e enovelado (verdade, realidade, ficção) que é literalmente impossível identificar a santa trilogia - o autor, a vida e a obra. Pessoa não teve história que se possa contar. Não apenas porque teve várias mas por uma espécie de ausência secreta de si mesmo, a qual talvez fosse apenas o outro nome da poesia. (1998,. p. 14)

Leyla Perrone-Moisés considera que Fernando Pessoa foi ninguém porque se anulou social e existencialmente na medida em que viveu a experiência da alteridade absoluta. Quer dizer, Fernando Pessoa foi tão e tanto outro que perdeu a possibilidade de reencontrar-se como unidade.

O narrador do Livro do desassossego, Bernardo Soares, tenta esclarecer: "para me criar, destruí-me. Tanto me exteriorizei dentro de mim, que dentro de mim não existo senão exteriormente. Sou a cena viva onde passam vários actores representando várias peças.“ (1995, p. 284)

Talvez seja o momento de se perguntar, mas, afinal quem é este Pessoa-ninguém, este sujeito vazio, este quarto heterônimo? É um fingidor. É um mistificador. Um produtor de vanguardas. Um nacionalista místico e um sebastianista racional. É um ocultista. O poeta dramático. O poetodrama.(expressão de Seabra). O poeta do drama estático. O poeta das quadras populares. É o poeta da "estética da abdicação" (a impossibilidade do real), porque "tudo é deserto" e do questionamento sobre esse mesmo real. E é, enfim, o poeta-mensageiro de um novo Portugal na épica moderna Mensagem.

O único real do poeta é o texto, sugere Perrone-Moysés (op. cit. p.184). "É onde um fingimento de poeta se tece por uma prática extrema de linguagem, que faz de todo o sujeito ficção/ fingidor e fingimento." Mas a parte isso e em contradição disso, Fernando Pessoa é muitas outras coisas. 
BERARDINELLI, Cleonice. Poesia e poética de Fernando Pessoa. Rio de Janeiro: Universidade do Brasil, 1958.

BRÉCHON, Robert. Fernando Pessoa Estranho Estrangeiro: uma biografia. Rio de Janeiro: Record, 1998.

CAMPOS, Álvaro de. Revista Portugal Futurista, Lisboa, 1917. p. 34

COELHO, Jacinto do Prado. Diversidade e unidade em Fernando Pessoa. Lisboa: Verbo, 1963.

CUADRADO, Perfecto E. Fernando Pessoa Máscaras y paradojas. Barcelona: Edhasa, 1996.

LOPES, Óscar \& SARAIVA, Antonio José. História da literatura portuguesa. Porto: Porto, 1990.

MENDONÇA, Antonio Sérgio de. A lição de Orpheu.

In: http://www.riototal.com.br/coojornal/antoniosergio009.htm Acesso em 17/09/2015 NIETSCHE, Col. Os Pensadores (trad. Rubens R. Torres Filho) . São Paulo, Abril, 1974. PAZ, Otávio. "O desconhecido de si mesmo". In: Signos em rotação. São Paulo: Perspectiva, 1996.

. Cuatrivio. Mexico: Joaquin Mortiz, 1969.

PERRONE-MOISÉS, Leyla. Fernando Pessoa: Aquém do eu, além do outro. São Paulo: Martins Fontes, 1990.

PESSOA, Fernando. Páginas de doutrina estética. sel. Jorge de Sena, Lisboa: Inquérito, s.d. . Páginas íntimas e de auto-interpretação. Sel. Jacinto do Prado Coelho e G. Rudolf Lind. Lisboa: Ática, 1966.

. Obras completas:Poemas de Alberto Caeiro. Lisboa: Ática, s.d.

- Obras completas:Poesias de Álvaro de Campos.. Lisboa: Ática, s.d.

- Obras completas:Poesias de Fernando Pessoa. Lisboa: Ática, s.d.

. Obras completas: Poesias inéditas de Fernando Pessoa (1919-1930). Lisboa:

Ática, s.d.

. Obras completas:Poesias inéditas de Fernando Pessoa (1930-1935). Lisboa:

Ática, s.d.

. Obras completas: Odes de Ricardo Reis. Lisboa: Ática, s.d.

Mensagem. Lisboa: Ática, s.d.

- Cartas de Fernando Pessoa a João Gaspar Simões.Lisboa, Europa-América, s.d.

. O banqueiro anarquista e outras prosas. São Paulo: Círculo do Livro, s.d.

. Livro do desassossego. Porto, Contexto, 1995.

REIS, Carlos. O conhecimento da literatura. Coimbra, Almedina, 1995.

SEABRA, José Augusto. Fernando Pessoa ou o poetodrama. São Paulo: Perspectiva, 1991.

SENA, Jorge de. Fernando Pessoa \& Cia. Heterônima: estudos coligidos. Lisboa: Setenta, 1984.

SIMÕES, João Gaspar. Fernando Pessoa: Breve história sua vida e sua obra. Lisboa: Difel, 1983.

. O mistério da poesia: ensaios de interpretação da gênese poética. Porto: Inova,1971.

- Vida e obra de Fernando Pessoa. História de uma geração. Lisboa: Bertrand, s.d SQUEFF, Maria Ozomar Ramos. A Filosofia na poesia de Fernando Pessoa. Porto Alegre, UFRGS, 1980.

TABUCCHI, Antonio e LANCASTER, Maria José. Fernando Pessoa. Paris: Hazan, 1997. 